\title{
Quality and Storage Stability of Bioactive Biodegradable Zein Protein Films Impregnated with Coliphages
}

\author{
Kanika Mahajan*, M.K. Chatli, Nitin Mehta and O.P. Malav
}

Department of Livestock Products Technology, College of Veterinary Science, Guru Angad Dev Veterinary and Animal Sciences University, Ludhiana, Punjab, India

*Corresponding author

\section{A B S T R A C T}

Present study was conducted for standardization of processing conditions for development of biodegradable Zein films and optimization of isolated Coliphage level to be incorporated in developed film. Zein films were formulated with varying concentrations of

\begin{tabular}{|c|}
\hline Keywords \\
\hline $\begin{array}{l}\text { Zein, Bioactive, } \\
\text { Coliphages, } \\
\text { Plaques, Glycerol }\end{array}$ \\
\hline Article Info \\
\hline $\begin{array}{l}\text { Accepted: } \\
10 \text { July } 2019 \\
\text { Available Online } \\
10 \text { August } 2019\end{array}$ \\
\hline
\end{tabular}
Zein, protein and glycerol, plasticizer. Three Zein levels 5\%, 6\%, 7\% with constant glycerol level as $7 \%$ and three glycerol levels $6.5 \%, 7 \%, 7.5 \%$ with constant Zein levels $5 \%$ were used to formulate films. Films were compared on basis of quality parameters for selection of optimum level of Zein and glycerol. Results depicted that density and film thickness increased with increase in Zein. Extensibility, penetrability, moisture decreased at higher concentration of Zein. With increase in glycerol, there was significant increase in thickness, density and extensibility but penetrability depicted only initial increase in films. On basis of above findings, 5\% Zein and 7\% glycerol was selected for development of bioactive film. Coliphages incorporated in Zein films were isolated by agar overlay technique. \% of buffer solution containing coliphages to be incorporated was selected on basis of diameter of inhibition halos. Storage stability of Zein films were evaluated for 4 weeks at $25 \pm 2{ }^{\circ} \mathrm{C}$. Results concluded that developed Zein films impregnated with $5 \%$ level of buffer containing $10^{10} \mathrm{pfu} / \mathrm{ml}$ coliphage can be stored at ambient temperature for 4 weeks without deteriorative changes in physico-mechanical and anti-microbial characteristics.

\section{Introduction}

Researchers, drug and food industries have shown enormous interest in the development of biodegradable films as these are alternative to traditional plastics. These biodegradable films enhance the quality of food, act as barrier for gas, moisture and provide protection to food after opening of primary package (Kim and Ustunol, 2001). Various sources are used in the production of biodegradable films like polysaccharides, lipids, proteins or combination of these. Protein based biodegradable films are found to be attractive with better mechanical and gas barrier properties in comparison to lipids and polysaccharides (Ou et al., 2004). Among the various protein sources, Zein formulated films are tough, glossy and grease-proof (Matthews et al., 2011). Zein is most important prolamin protein that dissolves in non-polar solvents (Dickey and Parris, 2002). The hydrophobic 
nature of Zein is due to high content of nonpolar amino acids (Shukla and Cheryan, 2001). In comparison to other proteins, films made from this alcohol soluble protein have high water vapor barrier properties (Guilbert, 1986). Rakotonirainy and Padua (2001) also reported that in Zein films water vapor was relatively low in comparison to hydrophilic biopolymers like cellophane, wheat gluten. In development of Zein films there is formation of hydrogen, hydrophobic and limited disulfide bonds between Zein chains (Guilbert, 1986). The hardness, brittleness, toughness of films can be corrected by addition of plasticizers that tend to increase flexibility (Corradini et al., 2014).

There has been rising interest in the recent years in formulation of functional Zein films by incorporation of antimicrobial and antioxidant agents for food application (Lungu and Johnson, 2005). Bioactive packaging systems with antimicrobial properties have gained popularity for the packaging of perishable livestock products including meat and meat products. Various polymers like chitosans, soy protein concentrate or composite materials impregnated with various natural antimicrobial substances nisin, eugenol etc. have been explored for extension of storage life of meat and meat products with a reduction in the microbial load on food products (Chatli et al., 2014; Rani et al., 2015; Chatli et al., 2016). The developed bioactive packaging systems used till date carried broad spectrum antimicrobials that did not target bacterial pathogen specifically. Thus, formulating pathogen specific antimicrobial active packaging systems is a innovative approach to improve the quality of food and safeguard against foodborne infections. Incorporation of bacteriophages in the Zein protein films is one such approach.

Bacteriophages are the viruses that are harmless to humans, animals but specifically infect bacteria. Bacteriophages that are specific to Escherichia coli include a number of morphological types that are mostly confined to T group (Bradley, 1963). The host specific property of bacteriophages favor them over other antimicrobials as they donot cause collateral harm to commensal microbiota (Sillankorva et al., 2012). Bacteriophages upon multiplication take over host protein machinery and either lead to integration of the genetic information into the bacterial chromosome without cell death (lysogenic pathway) or cause cell lysis (lytic pathway).

Lytic phages are one of the most harmless antibacterial approaches available towards a food safety perspective (Sillankorva et al., 2012). Thus present study was conducted to develop bioactive biodegradable Zein films incorporated with coliphages and determination of its physico-chemical quality and storage stability at room temperature.

\section{Materials and Methods}

\section{Source of materials}

Zein protein (RM4853) was procured from HiMedia Laboratories, Mumbai, India. Analytical grade chemicals, readymade media were procured from standard firms like Fisher Scientific, Amresco and Himedia. Coliphages were isolated against Escherichia coli (MTCC No. 2991) by agar overlay technique from sewage sample, which was collected from dairy farm, GADVASU, Ludhiana.

The pure culture of Escherichia coli (MTCC 2991) was procured from Microbial Type Culture Collection And Gene Bank, Institute of Microbial Technology (IMTECH), Chandigarh-160036, India. Escherichia coli is a Gram-negative, facultative anaerobic bacteria. Some serotypes cause serious food poisoning outbreaks and are responsible for recall of product (Vogt and Dippold, 2005) 
Standardization of the formulation and processing conditions for the development of Zein protein based biodegradable films

Optimization of level of Zein protein and glycerol for the development of biodegradable films

Three levels of Zein $(5 \%, 6 \%, 7 \%)$ with constant quantity of glycerol $(7 \%)$ and three levels of glycerol $(6.5 \%, 7 \%, 7.5 \%)$ using constant quantity of Zein (5\%) were dissolved in solvent absolute alcohol. The above solutions were heated at appropriate timetemperature combination. The mixture solutions casted on plastic petri plates (90x100mm) were dried for 8 hours. The developed films were stored at $25^{\circ} \mathrm{C}$ and $50 \%$ $\mathrm{RH}$ and further analyzed for various quality parameters. The optimum level of Zein and glycerol were selected for future trials.

Isolation and optimization of the level of incorporation of bacteriophage $\mathrm{T} 4$ (Coliphages) into the developed film

\section{Isolation of coliphages from sewage sample and their elution}

A mixture of double strength NZCYM broth (J865-500G), sewage supernatant and of Escherichia coli broth culture was incubated at $37^{\circ} \mathrm{C}$ for 24 hours. This processed sample was then filtered through $0.22 \mu \mathrm{m}$ PVDF filter (Axiva) and inoculated by agar overlay technique (McDuff et al., 1961) for isolation of coliphage. Plates having plaque formation (clear lysis, detected by naked eye, on E Coli lawn) were preserved and the plaques were confirmed for phage by secondary streaking.

The phage ensured by secondary streaking was eluted from the plates in SM buffer and was passed through $0.22 \mu \mathrm{m}$ PVDF filter (Table 1). It was then preserved at $4^{\circ} \mathrm{C}$ till further usage (Pandey et al., 2013).

\section{Estimation of the titre of coliphages}

The purified coliphages were serially diluted in SM buffer. Equal quantity of each phage dilution and Escherichia coli 6 hours broth culture was mixed in molten cooled semisolid NZCYM agar and then poured on preformed NZCYM + Nutrient agar.

The plaques produced were counted and multiplied by dilution factor to arrive at the phage titre. The titre was expressed in plaque forming units (pfu/ml).

Incorporation of coliphages into the developed bioactive film

As per standardized levels of formulation, Zein and glycerol combination (Zein protein $5 \mathrm{w} / \mathrm{v} \%$, Glycerol $7 \mathrm{w} / \mathrm{v} \%$ ) were selected for the development of bioactive biodegradable films and three levels of coliphages were incorporated in the developed bioactive film as: T1 (1\%. v/v); T2 (3\% v/v); T3 (5\% v/v). T3 $(5 \%)$ formed inhibition halos of largest diameter and thus storage stability of these coliphage impregnated films were evaluated for 4 weeks under ambient storage conditions of $\left(25 \pm 2^{\circ} \mathrm{C}\right)$ (Fig. 1). The films were stored after being packaged in LDPE bags and drawn at weekly intervals to test the physicomechanical and antimicrobial efficacy. The antimicrobial efficacy of the films was analyzed by disc agar diffusion method and the diameters of inhibitory halos around the films were measured with the help of digital vernier caliper.

\section{Processing quality characteristics of Zein protein films}

\section{Water Vapor Transmission Rate (WVTR)}

Modified ASTM 96-00 method was used to measure Water vapor transmission rate (ASTM 2000). 


\section{Moisture Content (MC)}

Gravimetric method was used to determine moisture content of films. The films weighing $500 \mathrm{mg}$ were dried at $105 \pm 1^{\circ} \mathrm{C}$ for $24 \mathrm{~h}$. The weight loss of the sample was determined and $\mathrm{MC}$ was calculated as the percentage of water removed from the system.

\section{Film thickness and density}

Film thickness was measured with an electronic digital micrometer (Forbes Gokak Limited, Measuring Instrument, Aurangabad, India) and density of the film was determined using a floatation method at $25^{\circ} \mathrm{C}$.

Density $(\mathrm{g} / \mathrm{ml})=\frac{\mathrm{V}_{1} \mathrm{~d}_{1}+\mathrm{V}_{2} \mathrm{~d}_{2}}{\mathrm{~V}_{1}+\mathrm{V}_{2}}$

Where, $\mathrm{V}_{1^{-}}$volume of heptane in $\mathrm{ml}, \mathrm{V}_{2^{-}}$ volume of $\mathrm{CCL}_{4}$ in $\mathrm{ml}, \mathrm{d}_{1}$ - density of heptane in $\mathrm{g} / \mathrm{ml}, \mathrm{d}_{2}$ - density of $\mathrm{CCL}_{4}$ in $\mathrm{g} / \mathrm{ml}$

\section{Penetrability}

Penetrability was calculated automatically by the preloaded software in the texture analyzer (TMS-PRO, Food Technology Corporation, USA) from the force-time plot.

\section{Transmittance}

Transmittance of Zein protein films was determined by UV-VIS spectrophotometer (Elico SL-159, Mumbai, India).

\section{Color profile analysis}

CR-400, Konica Minolta, chromameter (Japan) was used to measure color profile known as $L^{*}, a^{*}, b^{*}$ values. $L^{*}$ denotes (brightness 100) or lightness (0), $a^{*}(0+$ redness/- greenness), $b^{*}$ (+ yellowness/blueness) values.

\section{Disc agar diffusion method}

Bioactive films impregnated with coliphages were placed on the $E$ coli lawn. Thereafter, the plate containing bioactive films and bacterial lawn were incubated at $37^{\circ} \mathrm{C}$ for 24 hours. The diameter of inhibitory halos around the films was then measured.

\section{Statistical analysis}

The data obtained from different set of each experiments were subjected to statistical analysis (Snedecor and Cochran, 1994) for one way Analysis of Variance (ANOVA) on Completely Randomized design (CRD) and Duncans multiple range test (DMRT) to compare the means with standard error (SE) by using SPSS-16.0 (SPSS Inc. Chicago IL, USA). The whole set of experiments were repeated three times for the consistency of the results. The samples for each parameter were drawn in duplicate leading to observation 6 $(\mathrm{n}=6)$. The statistical difference was expressed at $5 \%$ level of experiment.

\section{Results and Discussion}

Effect of various levels of Zein on the quality characteristics of developed Zein protein based biodegradable films (Table 2)

It was observed that film thickness increased with increase in level of Zein. This might be due to the higher available quantity of the gel forming protein in formulation. Sharma and Luzinov (2013) also reported increase in thickness with increase in protein concentration as incorporated protein lead to increase in the viscosity of film forming solution. Rani et al., (2015) and Singh et al., (2015) also reported increase in the thickness of film with the increase in whey protein concentrate and chitosan, respectively in the film forming solution. 
Density $(\mathrm{g} / \mathrm{ml})$ is considered as indicator of weight of films and its behavior in packaging of high moisture meat products. Higher the density, heavier is film and vice-versa. Density increased with the increased level of Zein and this might be due to higher content and weight of Zein in the formulation.

Extensibility is measure of plasticity of films and indicate extent to stretch before they rupture (Cuq et al., 1998). It is used as a measure of pliability, flexibility and resilience of films. Extensibility was comparable in T1 and T2 where as decreased significantly $(\mathrm{P}<0.05)$ in $\mathrm{T} 3$. Results clearly indicate that there is decline in flexibility and pliability of films with increase in Zein protein content in formulation. These results are in consonance with our results on film thickness.

Penetrability is measure of resistance of films against puncturing. The higher mechanical property is required to maintain film integrity during handling or while packaging, the "bone in" meat chunks or carcasses which may pierce the packaging material. Penetrability was measured highest in T2 and lowest in T3. These results reflected that integral strength of the films declined at higher concentration of Zein. It might be due to the higher packing density of protein particles at higher concentration level. However various researchers have reported the changes in penetrability with varying level and type of plasticizer (Nemet et al., 2010).

Water vapor transmission rate is important property of packaging material as it depicts permeability of films to moisture transfer between food and atmosphere which ultimately determines the deteriorative changes in food products. WVTR was comparable in all treated products. The lower value of WVTR is attributable to the hydrophobic nature of Zein protein. Wellar et al., (1998) also reported that WVTR was not significantly $(\mathrm{P}<0.05)$ affected with rise or decline in concentration of Zein.

Transmittance is indicator of visibility through films. Higher the transmittance, better the visibility of the product. Further it also tells us about light barrier properties of films, which is an important criterion to measure lipid oxidation induced by UV light in the food system. Results in Table 2 revealed that transmittance decreased with rise in concentration of Zein and it was significantly $(\mathrm{P}<0.05)$ higher in $\mathrm{T} 1$ and $\mathrm{T} 2$. Lowering of transmittance is attributed to the increase in film thickness with increase in concentration level of Zein.

Total moisture content in packaging films is correlated with storage life of films. Higher moisture content, higher the chances of the growth of the microbes and subsequently putrification of protein based films. Moisture percentage in the films followed a decreasing trend with increase in concentration level of Zein in the formulation of biodegradable films. It might be due to the quality characteristics of Zein, which is hydrophobic in nature (Lawton, 2004). Further, there was no added water in the formulation and the non-polar alcohol was used as solvent in the present study.

Color attributes of biodegradable packaging films are of immense importance as they directly influence the consumer acceptability by affecting the appearance of the product. Lightness value decreased linearly with increase in concentration level. It was recorded minimum for $\mathrm{T} 3$ and maximum for T1. The lowering of lightness can be correlated with higher concentration of pigments xanthophylls contributed by the proteins and increase in thickness of film. These results are in accordance with our observations on film thickness and transmittance as evident in Table 2. 
Redness increased significantly $(\mathrm{P}<0.05)$ with the rise in level of Zein protein. The films were darker in $\mathrm{T} 3$ than $\mathrm{T} 1$ and $\mathrm{T} 2$. The increase in redness value might be due to breakdown of proteins and pigments at an acidic $\mathrm{pH}$ of 5 of the formulation mix. Yellowness increased significantly with increase in each level of treatments. The higher level of yellowness is attributable to innate pigment xanthophyll present in corn protein. On basis of various quality characteristics discussed above and keeping in view the economics of the film production, $5 \%$ level of Zein protein was selected to develop a film of optimum thickness, better penetrability and color profile parameters.

Effect of various levels of glycerol on the quality characteristics of developed Zein protein based biodegradable films (Table 3)

It was observed that thickness of films increased with increase in level of glycerol. The thickness values was recorded lowest for T1 and highest for T3. Higher concentration of glycerol, higher the content of dry matter in the film forming solution which directed the thickness of resulting films (Nemet et al., 2010). The variation in thickness in Table 2 and 3 for the same level of Zein protein $(5 \%)$ can be correlated with the change in glycerol level in formulation. In Table 2, 5\% Zein and $7 \%$ glycerol level (T1) had higher thickness than 5\% Zein with $6.5 \%$ glycerol (T1) in Table 3. These results are in accordance with the findings of Chillo et al., (2008), Nemet et al., (2010) recorded for different types of biodegradable films.

An increase in glycerol concentration resulted a significant increase in density of film. It was recorded highest for $\mathrm{T} 3$ and lowest for $\mathrm{T} 1$ which can be correlated with thickness values of film. Similar findings were reported by Jandyal (2016) for soy protein based films.

Extensibility increased significantly in $\mathrm{T} 2$ and T3 than T1. The extensibility was recorded highest for $\mathrm{T} 3$ and lowest for $\mathrm{T} 1$. The increase in extensibility with increase in level of plasticizer is due to decrease in inter molecular forces along the polymer chains imparting increase in film flexibility (Chillo et al., 2008). Caner et al., (1998) also reported increase in extensibility and improvement in barrier properties of chitosan film with the increase in level of plasticizer.

Fig.1 Inhibition halos of coliphages against Escherichia coli

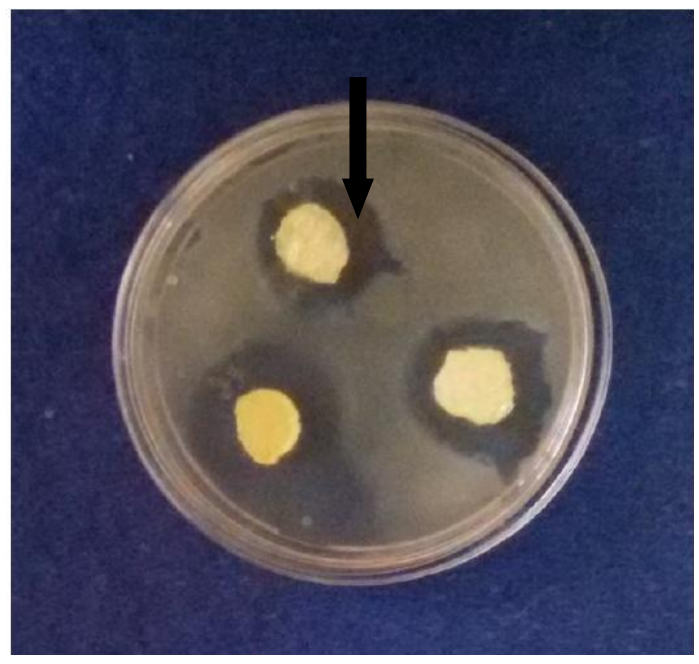


Table.1 Composition of SM buffer

\begin{tabular}{|l|l|}
\hline Components & Quantity \\
\hline Sodium Chloride $(\mathrm{NaCl})$ & $5.8 \mathrm{~g}$ \\
\hline Magnesium Sulphate $\left.\mathbf{( M g S O}_{\mathbf{4}} \mathbf{. 7 \mathbf { H } _ { 2 }} \mathbf{O}\right)$ & $2.0 \mathrm{~g}$ \\
\hline Gelatin $(\mathbf{2 \%})$ & $5.0 \mathrm{ml}$ \\
\hline $\mathbf{1}$ M Tris $\mathbf{H C l}(\mathbf{p H}-\mathbf{7 . 5})$ & $50.0 \mathrm{ml}$ \\
\hline
\end{tabular}

Table.2 Effect of different levels of Zein protein on the characteristics of biodegradable films $(\mathrm{Mean} \pm \mathrm{SE})^{*}$

\begin{tabular}{|l|c|c|c|}
\hline \multirow{2}{*}{ Parameters } & \multicolumn{3}{|c|}{ Treatments } \\
\cline { 2 - 4 } & $\mathbf{T 1}$ & $\mathbf{T 2}$ & T3 \\
\hline Thickness $(\boldsymbol{\mu m})$ & $201.66 \pm 0.49^{\mathrm{a}}$ & $205.83 \pm 0.60^{\mathrm{b}}$ & $251.33 \pm 0.55^{\mathrm{c}}$ \\
\hline Density $(\mathbf{g} / \mathbf{m l})$ & $1.21 \pm 0.01^{\mathrm{a}}$ & $1.24 \pm 0.01^{\mathrm{b}}$ & $1.26 \pm 0.02^{\mathrm{c}}$ \\
\hline Extensibility(N) & $6.40 \pm 0.08^{\mathrm{b}}$ & $6.38 \pm 0.07^{\mathrm{b}}$ & $4.31 \pm 0.03^{\mathrm{a}}$ \\
\hline Penetrability(N) & $3.35 \pm 0.04^{\mathrm{b}}$ & $3.74 \pm 0.13^{\mathrm{c}}$ & $3.14 \pm 0.01^{\mathrm{a}}$ \\
\hline WVTR $\left(\mathbf{g} / \mathbf{m}^{\mathbf{2}} \mathbf{t}\right)$ & $0.0076 \pm 0.001^{\mathrm{a}}$ & $0.0078 \pm 0.001^{\mathrm{a}}$ & $0.0078 \pm 0.001^{\mathrm{a}}$ \\
\hline Transmittance $(\boldsymbol{\%})$ & $19.87 \pm 0.19^{\mathrm{b}}$ & $19.86 \pm 0.19^{\mathrm{b}}$ & $19.16 \pm 0.11^{\mathrm{a}}$ \\
\hline Moisture $(\boldsymbol{\%})$ & $18.71 \pm 0.09^{\mathrm{c}}$ & $17.72 \pm 0.08^{\mathrm{b}}$ & $16.67 \pm 0.08^{\mathrm{a}}$ \\
\hline Lightness $\left(\boldsymbol{L}^{*}\right)$ & $76.88 \pm 0.23^{\mathrm{c}}$ & $74.56 \pm 0.35^{\mathrm{b}}$ & $71.46 \pm 0.33^{\mathrm{a}}$ \\
\hline Redness $\left(\boldsymbol{a}^{*}\right)$ & $6.38 \pm 0.18^{\mathrm{a}}$ & $9.9 \pm 0.24^{\mathrm{b}}$ & $10.94 \pm 0.30^{\mathrm{c}}$ \\
\hline yellowness $\left(\boldsymbol{b}^{*}\right)$ & $49.14 \pm 0.15^{\mathrm{a}}$ & $59.80 \pm 0.41^{\mathrm{b}}$ & $61.07 \pm 0.36^{\mathrm{c}}$ \\
\hline
\end{tabular}

$\mathrm{n}=6$, T1: 5\%; T2:6\%; T3:7.0\% Zein; $7 \%$ Glycerol

$*$ Mean \pm S.E. with different superscripts row-wise $(\mathrm{a}-\mathrm{c})$ differ significantly $(\mathrm{P}<0.05)$

Table.3 Effect of different levels of glycerol on the characteristics of Zein protein based biodegradable films $(\text { Mean } \pm \mathrm{SE})^{*}$

\begin{tabular}{|l|c|c|c|}
\hline \multirow{2}{*}{ Parameters } & \multicolumn{3}{|c|}{ Treatments } \\
\cline { 2 - 4 } & T1 & T2 & T3 \\
\hline Thickness $(\boldsymbol{\mu m})$ & $187.16 \pm 0.47^{\mathrm{a}}$ & $202.33 \pm 0.49^{\mathrm{b}}$ & $220.50 \pm 0.43^{\mathrm{c}}$ \\
\hline Density $(\mathbf{g} / \mathbf{m l})$ & $1.21 \pm 0.01^{\mathrm{a}}$ & $1.25 \pm 0.01^{\mathrm{b}}$ & $1.28 \pm 0.02^{\mathrm{c}}$ \\
\hline Extensibility(N) & $6.25 \pm 0.16^{\mathrm{a}}$ & $6.59 \pm 0.07^{\mathrm{b}}$ & $6.69 \pm 0.04^{\mathrm{b}}$ \\
\hline Penetrability(N) & $3.19 \pm 0.04^{\mathrm{a}}$ & $3.55 \pm 0.04^{\mathrm{b}}$ & $3.12 \pm 0.17^{\mathrm{a}}$ \\
\hline WVTR $\left(\mathbf{g} / \mathbf{m}^{\mathbf{2}} \mathbf{t}\right)$ & $0.0074 \pm 0.001^{\mathrm{a}}$ & $0.0074 \pm 0.001^{\mathrm{a}}$ & $0.0079 \pm 0.001^{\mathrm{b}}$ \\
\hline Transmittance(\%) & $19.89 \pm 0.19^{\mathrm{a}}$ & $20.48 \pm 0.21^{\mathrm{ab}}$ & $20.52 \pm 0.19^{\mathrm{b}}$ \\
\hline Moisture(\%) $(\%)$ & $16.38 \pm 0.14^{\mathrm{a}}$ & $17.56 \pm 0.05^{\mathrm{b}}$ & $18.21 \pm 0.05^{\mathrm{c}}$ \\
\hline Lightness $\left(\boldsymbol{L}^{*}\right)$ & $76.56 \pm 0.06^{\mathrm{a}}$ & $76.77 \pm 0.08^{\mathrm{a}}$ & $77.06 \pm 0.11^{\mathrm{b}}$ \\
\hline Redness $\left(\boldsymbol{a}^{*}\right)$ & $6.59 \pm 0.15^{\mathrm{a}}$ & $6.36 \pm 0.15^{\mathrm{a}}$ & $6.27 \pm 0.12^{\mathrm{a}}$ \\
\hline Yellowness $\left(\boldsymbol{b}^{*}\right)$ & $50.64 \pm 0.26^{\mathrm{a}}$ & $49.11 \pm 0.20^{\mathrm{a}}$ & $51.52 \pm 0.21^{\mathrm{a}}$ \\
\hline
\end{tabular}

$\mathrm{n}=6$, T1: $6.5 \% ; \mathrm{T} 2: 7 \%$; T3:7.5\% Glycerol; $5 \%$ Zein

$*$ Mean \pm S.E. with different superscripts row-wise $(\mathrm{a}-\mathrm{c})$ differ significantly $(\mathrm{P}<0.05)$ 
Table.4 Mean Diameter of inhibition halos of coliphages against Escherichia coli with the addition of different levels of coliphage buffer solution (Mean \pm S.E)

\begin{tabular}{|l|l|}
\hline Film impregnated with coliphages & Diameter $(\mathbf{c m})$ \\
\hline Control & $1.00 \pm 0.00^{\mathrm{a}}$ \\
\hline T1 (1\%) & $1.45 \pm 0.04^{\mathrm{b}}$ \\
\hline T2 (3\%) & $1.60 \pm 0.05^{\mathrm{c}}$ \\
\hline T3 (5\%) & $1.75 \pm 0.04^{\mathrm{d}}$ \\
\hline
\end{tabular}

$\mathrm{n}=6, \mathrm{~T} 1: 1.0 \% ; \mathrm{T} 2: 3.0 \% ; \mathrm{T} 3: 5.0 \%$ coliphages

*Mean \pm S.E. with different superscripts column-wise (a-d) differ significantly $(\mathrm{P}<0.05)$

Table.5 Antimicrobial and physico-mechanical properties of films incorporated with coliphages $($ Mean \pm S.E; $n=6)$

\begin{tabular}{|l|c|c|c|c|c|}
\hline Diameter/Days & Day 1 & Day 7 & Day 14 & Day 21 & Day 28 \\
\hline $\begin{array}{l}\text { Mean Diameter } \\
\text { of } \begin{array}{c}\text { Inhibition } \\
\text { halos }(\mathbf{c m})\end{array}\end{array}$ & $1.75 \pm 0.05$ & $1.74 \pm 0.04$ & $1.74 \pm 0.05$ & $1.70 \pm 0.04$ & $1.71 \pm 0.06$ \\
\hline Thickness( $\boldsymbol{\mu m})$ & $201.33 \pm 0.49$ & $201.66 \pm 0.44$ & $201.75 \pm 0.48$ & $201.89 \pm 0.53$ & $201.95 \pm 0.54$ \\
\hline Extensibility(N) & $6.35 \pm 0.16$ & $6.36 \pm 0.18$ & $6.36 \pm 0.21$ & $6.32 \pm 0.19$ & $6.31 \pm 0.23$ \\
\hline Penetrability(N) & $3.19 \pm 0.04$ & $3.21 \pm 0.07$ & $3.22 \pm 0.05$ & $3.24 \pm 0.03$ & $3.19 \pm 0.05$ \\
\hline
\end{tabular}

Penetrability was significantly $\quad(\mathrm{P}<0.05)$ higher in $\mathrm{T} 2$ than $\mathrm{T} 1$ and $\mathrm{T} 3$. It increased initially with increase in glycerol but decreased thereafter with higher concentration of glycerol. It might be due to ability of plasticizer to expand the protein molecule chain, which facilitates the mobility on the plane of film leading to the direction of the deformation and increasing puncture deformation of the films (Leceta et al., 2013). Similar results were documented by Singh et al., (2015) about lowering of penetrability value with increase in glycerol content in formulation of chitosan based films.

WVTR increased with increase in glycerol. It was recorded lowest in T1 and highest in T3. The increase in WVTR with rise in glycerol level might be due to fact that glycerol provides higher amount of polar groups in film. Various researchers have reported significant increase in WVTR with increase in glycerol level in formulation. Singh et al., (2015), Jandyal (2016), Rani (2014) have postulated that increase in glycerol concentration lead to increase in inter chain spacing and bio polymer mobility within the film matrix and decrease in internal hydrogen bonding with in the film structure leading to increase in diffusion of water molecules. However, lower increase in WVTR in present study might be due to use of absolute alcohol as solvent in formulation mixture. Higher alcohol concentration allowed greater intermolecular forces between protein chains preventing water vapor migration through the film.

Transmittance increased with increase in level of glycerol. It was significantly $(\mathrm{P}<0.05)$ higher in T3 than T1. Similar findings were reported by Yan et al., (2012). Film transparency/opacity plays a vital role when film is used to cover light sensitive products, in such cases opaque film is desirable (PenaSerna and Lopes-Filho, 2013). The changes in transmittance/opacity are due to interaction between solvent (ethanol) and glycerol. 
Ethanol results in better Zein solubilisation leading to increase in the amount of intermolecular forces between protein chains and between proteins resulting in stronger and denser matrix, which prevented the light to pass through the films, whereas the glycerol due to its transparent nature and mobility increases the dispersion of film matrix leading to decrease in opacity.

Hence, the overall results are directed by the concentration and level of ethanol, glycerol, and type of proteins, and composition of the multi component composite films (PenaSerna and Lopes-Filho, 2013).

Moisture percentage increased in all treatments. This might be due to higher hydrophilicity of glycerol used in film formation. In general, moisture percentage in all developed films was lower due to hydrophobic nature of protein and use of alcohol as a solvent. Karbowiak and coworkers (2006) also reported that moisture content of the bio polymer based films varied greatly due to addition of plasticizer which control the water molecule mobility and adsorption/absorption properties of the water molecules in the film matrix (Pena-Serna and Lopes-Filho, 2013).

The instrumental color profile is important parameter for the packaging film as it directs consumer acceptability and marketability.

Lightness was increased with increase in glycerol level. It was measured significantly $(\mathrm{P}<0.05)$ higher in $\mathrm{T} 3$ than $\mathrm{T} 1$ and $\mathrm{T} 2$. Lightness value increased with the increase in glycerol concentration and similar results were documented by Chillo et al., (2008) in Chitosan films, Jandyal (2016) in SPI films, Garcia et al., (2004) in composite hydrocolloid films. It could be due to colorless nature of glycerol, which might have diluted the overall color of a film with its increasing concentration in the film forming solution (Sobral et al., 2001).

Yellowness and redness of films also followed a decreasing trend. However, the results did not vary significantly $(\mathrm{P}<0.05)$ with an increase in concentration of glycerol. The comparable color attributes of the film in a present study might be due to the constant level of Zein protein and solvent used in the film development. In view of above results and discussions, 5\% Zein and 7\% glycerol (T2) is selected for further study to develop bioactive biodegradable film.

\section{Isolation of coliphages from sewage sample}

Coliphages used as an antimicrobial agent in the experiment were isolated from sewage sample by agar overlay technique against actively growing Escherichia coli. The presence of phages was confirmed by primary and secondary streaking and thereafter, the phages were eluted from positive plates in SM buffer and stored at $4{ }^{\circ} \mathrm{C}$ till further usage. Similar steps for isolation of brucellaphages were documented by Chachra et al., (2012).

Incorporation of coliphages into the developed biodegradable film

Three levels of coliphages T1 (1\%), T2 (3\%), T3 $(5 \%)$ having the same concentration of $10^{10} \mathrm{pfu} / \mathrm{ml}$ were incorporated in the standardized Zein film forming solution. The film solution was dried for 8 hours to obtain the desired film. Thereafter, efficacy of coliphages in the films was tested by in vitro disc agar diffusion method. The results in Table 4 clearly depicted that halo size increased linearly with the rise in level of incorporation of buffer solution containing bacteriophages. The increase in halo size reflect the inhibitory efficiency of coliphages against Escherichia coli. The halo size increased in dose dependent manner. The no. 
of plaque forming unit of coliphages $\left(10^{10}\right.$ $\mathrm{pfu} / \mathrm{ml}$ ) were constant in each $\mathrm{ml}$ of buffer solution, however the amount of buffer solution was higher. Therefore, more number of cells was available for the lysis of Escherichia coli bacterial cells. This has been reflected through the increase in halo size. T3 (5\%) formed inhibition halos of largest diameter and hence treatment T3 (5\%) was selected for incorporation in developed Zein films.

\section{Storage stability of biodegradable films}

Storage stability of films incorporated with selected level (T3:5\%) of coliphages was evaluated at ambient temperature $\left(25 \pm 2{ }^{\circ} \mathrm{C}\right)$ on the basis of biophysical and antimicrobial efficacy. The antimicrobial efficacy of coliphage impregnated films against Escherichia coli culture was evaluated on the basis of inhibition halos. Results in Table 5 reveal that the mean diameter of inhibition halos did not vary significantly $(\mathrm{P}<0.05)$ with the increase in storage days. The diameter of inhibition halos on $1^{\text {st }}$ day was comparable to halos measured on $28^{\text {th }}$ day of storage. The results are in contrast to the observations recorded by (Gouvea et al., 2015). The authors documented that bacteriophages were no longer effective in acetate films after 14 days of storage. The variation in present study is attributed to change in matrix material, process protocol and type of bacteriophage.

Physico-mechanical properties (Table 5) viz thickness, extensibility, penetrability displayed values on $1^{\text {st }}$ day of storage which were comparable to $28^{\text {th }}$ day of storage. Nonsignificant $(\mathrm{P}<0.05)$ variation in thickness, penetrability etc. during storage can be attributed to hydrophobic nature of Zein protein which inhibit the imbibing of moisture from atmosphere, main predisposable factor the deteriorative change in physic-mechanical properties of biodegradable films. Results concluded that developed bioactive biodegradable films from Zein protein and impregnated with 5\% level of buffer solution containing $10^{10} \mathrm{pfu} / \mathrm{ml}$ bacteriophage can be successfully stored at ambient temperature for 4 weeks without any deteriorative changes in physico-mechanical and anti-microbial quality characteristics.

\section{Acknowledgement}

Authors are highly gratified to Dean and Head of Department (HOD) of Livestock Products Technology, GADVASU, Ludhiana for providing us the timely guidance, necessary equipments and financial support.

Zein is an expensive protein and levels as high as $31 \%$ have been used for biodegradable film formation by various researchers including Marcos et al., 2007. Thus in an attempt to make cost effective films, level of Zein protein was reduced to $5 \%$. Zein films were hence formulated with optimum physico-chemical and antimicrobial property. The results concluded that bioactive biodegradable films can be formulated using $5 \%$ Zein and $7 \%$ glycerol. These films on impregnation with $5 \%$ level of buffer solution containing $10^{10} \mathrm{pfu} / \mathrm{ml}$ bacteriophages can be successfully stored at ambient temperature for 4 weeks without any deteriorative changes in physico-mechanical and anti-microbial quality characteristics.

\section{References}

Andrianaivo, M. Rakotonirainy., and Graciela, W. Padua. 2001. Effects of Lamination and Coating with Drying Oils on Tensile and Barrier Properties of Zein. Journal of Agricultural and Food Chemistry. 49: 2860-2863.

Bradley, D.E. 1963. The Structure of Coliphages. Journal of general microbiology.31: 435445

Caner, C., Vergano, P. J., and Wiles, J.L.1998. 
Chitosan film mechanical and permeation properties as affected by acid, plasticizer, and storage. Journal of Food Science 63(6): 1049-1053.

Chachra, D., Kaur, H., Chandra, M., and Saxena, H. M. 2012. Isolation, electron microscopy and physicochemical characterization of a brucellaphage against Brucella abortus vaccine strain S19. International Journal of Microbiology. 10(2): 1-7.

Chatli, M. K., Kaura, S., Jairath, M., Mehta, N., Kumar, P., and Sahoo, J.2014. Storage stability of raw chevon chunks packaged in composite, bioactive films at refrigeration temperature. Animal Production Science. 54(9): 1328-1332.

Chatli, M. K., Rani, R., Mehta, N., and Kumar, P.2016. Storage stability of pork nuggets wrapped with composite antimicrobial biodegradable films under different packaging conditions. Proceeding $62^{\text {nd }}$ International Congress of Meat Science and Technology Thailand, pp. 19-23.

Chillo, S., Flores, S., Mastromatteo, M., Conte, A., Gerschenson, L., and Del Nobile, M. A.2008. Influence of glycerol and chitosan on tapioca starch-based edible film properties. Journal of Food Engineering. 88(2): 159-168.

Corradini, E., Curti, P.S., Meniqueti, A.B., Martins, A.F., Rubira, A. F., and Muniz, E.C.2014. Recent advances in foodpacking, pharmaceutical and biomedical applications of Zein and Zein-based materials. International journal of molecular sciences. 15(12): 22438-22470.

Cuq, B., Gontard, N., and Guilbert, S.1998. Proteins as agricultural polymers for packaging production. Cereal Chemistry. 75(1):1-19.

Dickey, L. C., and Parris, N.2002. Serial batch extraction of Zein milled maize. Industrial Crops and Products an International Journal. 15: 33-42.

Garcia, M. A., Pinotti, A., Martino, N. M., and Zaritzky, N. E.2004. Characterization of composite hydrocolloid film. Carbohydrate Polymers. 56: 339-345.

Gouvea, D. M., Mendonça, R. C. S., Soto, M. L., and Cruz, R. S.2015. Acetate cellulose film with bacteriophages for potential antimicrobial use in food packaging. LWT-Food Science and Technology. 63(1): 85-91.

Guilbert, S.1986. Technology and application of edible protective films. In: Mathlouthi M (Ed.) Food Packaging and Preservation, pp. 371-394.

Jandyal, M. 2016. 'Development of soy protein isolate based biodegradable bioactive films for the storage stability of fibre enriched egg kofta'. M.V.Sc. Thesis, Guru Angad Dev Veterinary and Animal Sciences University, GADVASU, Ludhiana, India.

Karbowiak, T., Hervet, H., Léger, L., Champion, D., Debeaufort, F., and Voilley, A. 2006. Effect of plasticizers (water and glycerol) on the diffusion of a small molecule in iota-carrageenan biopolymer films for edible coating application. Biomacromolecules. 7(6): 2011-2019.

Kim, S. J., and Ustunol, Z. 2001. Thermal properties, heat sealability and seal attributes of whey protein isolate/lipid emulsion edible films. Journal of Food Science 66: 985-990.

Lawton, J. W.2004. Plasticizers for Zein: their effect on tensile properties and water absorption of Zein films. Cereal Chemistry 81(1): 1-5.

Leceta, I., Guerrero, P., and Caba, K.D.L.2013. Functional properties of chitosan-based films. Carbohydrate polymers 93(1): 339346.

Lungu, B., and Johnson, M.G. 2005. Potassium sorbate does not increase control of Listeria monocytogenes when added to Zein Coatings with nisin on the surface of full fat turkey frankfurter pieces in a model system at $4^{\circ}$ C. J. Food Sci 70 (2): 95-99.

Marcos, B., Aymerich, T., Monfort, J.M., and Garriga, M. 2007. Use of antimicrobial biodegradable packaging to control Listeria monocytogenes during storage of cooked ham. International Journal of Food Microbiology. 120(1-2):152-158.

Matthews, L.B., Kunkel, M.E., Acton, J. C., Ogale, A.A., and Dawson, P.L. 2011. Bioavailability of soy protein and corn 
Zein films. Food and Nutrition Sciences. 2: 1105-1113.

McDuff, C.R., Jones, L.M., Wilson, J.B. 1961. Characteristics of brucellaphages. Journal of Bacteriology. 83:324-329.

Nemet, N.T., Soso, V.M., and Lazic, V. L.2010. Effect of glycerol content and $\mathrm{pH}$ value of film forming solution on the functional properties of protein based edible films. Acta Periodica Technologica. 41: 57-67.

Ou, S., Kwok, K.C., and Kang, Y. 2004. Changes in in vitro digestibility and available lysine of soy protein isolate after formation of film. Journal of Food Engineering. 64: 301-305.

Pena-Serna, C., Lopes-Filho, J. F.2013. Influence of ethanol and glycerol concentration over functional and structural properties of Zein-oleic acid films. Materials Chemistry and Physics 142(2): 580-585.

Rani R.2014. 'Development of milk protein based edible films for the extension of shelf life of functional chicken meat bullets'. M.V.Sc. Thesis submitted to Guru Angad Dev Veterinary and Animal Sciences University, Ludhiana, India.

Rani, R., Chatli, M. K., Jairath, M., Mehta, N., and Kumar, P.2015. Storage stability of functional chicken meat bullets coated with composite antimicrobial biodegradable films under different packaging conditions. Animal Production Science. 56(11): 1953-1960.

Shalini, P., Chachra, D. and Saxena, H.M. 2013. Protein profiling and physico-chemical characterization of an isolated phage against Brucella abortus strain 19. African Journal of Microbiology Research. 7(14):1233-1238.

Sharma, S., and I. Luzinov. 2013. Whey based binary bioplastics. Journal of Food
Engineering. 119 (3): 404-410.

Shukla. R., and Cheryan, M. 2001. Zein: The industrial protein from corn. Industrial Crops and Products an International Journal. 13: 171-192.

Sillankorva, S.M., Oliveira, H., and Azeredo, J.2012. Bacteriophages and their role in food safety. International Journal of Microbiology, 2012:1-13.

Singh, T.P., Chatli, M.K., and Sahoo, J.2015. Development of chitosan based edible films: process optimization using response surface methodology. Journal of food science and technology 52(5): 25302543.

Snedecor, G. W., and Cochran, W. G.1994. Statistical Methods, $8^{\text {th }}$ Edn., Iowa State University press, Ames, Iowa.

Sobral, P.J.A., Menegalli, F.C., Hubinger, M.D, and Roques, M.A. 2001. Mechanical, water vapour, barrier and thermal properties of gelatin based edible film. Food Hydrocolloids 15: 423-342.

Vogt, R.L., and Dippold, L. 2005. "Escherichia coli $0157: \mathrm{H7}$ outbreak associated with consumption of ground beef, June-July 2002". Public Health Reports. 120 (2): 174-178.

Weller, C. L., Gennadios, A., and Saraiva, R. A.1998. Edible bilayer films from Zein and grain sorghum wax or carnauba wax. LWT-Food Science and Technology 31(3): 279-285.

Yan, Q., Hou, H., Guo, P., Dong, H.2012. Effect of extrusion and glycerol content on properties of oxidized and acetylated corn starch-based films. Carbohydrate Polymer 87: 707-712.

\section{How to cite this article:}

Kanika Mahajan, M.K. Chatli, Nitin Mehta and Malav, O.P. 2019. Quality and Storage Stability of Bioactive Biodegradable Zein Protein Films Impregnated with Coliphages. Int.J.Curr.Microbiol.App.Sci. 8(08): 964-975. doi: https://doi.org/10.20546/ijcmas.2019.808.112 